\section{z Filologii Polskiej i Słowiańskiej}

DOI: $10.11649 /$ sfps.2012
Article No. 2012

\section{Citation:}

Łuczak, A. (2021). Próby tworzenia polskich terminów gramatycznych: Na przykładzie rękopisów Bartłomieja z Bydgoszczy. Studia z Filologii Polskiej i Słowiańskiej, 56, Article 2012. https:// doi.org/10.11649/sfps.2012

\author{
Arleta Łuczak \\ (Instytut Slawistyki Polskiej Akademii Nauk, Warszawa)
}

\title{
Próby tworzenia polskich terminów gramatycznych. Na przykładzie rękopisów Bartłomieja z Bydgoszczy
}

W nurt pierwszych prób kształtowania się polskiej terminologii gramatycznej wpisuje się słownictwo zawarte w dwóch łacińsko-polskich manuskryptach Bartłomieja z Bydgoszczy z roku 1532 i 1544. W latach 1999-2019 ukazała się w sześciu częściach polsko-łacińska, czyli „odwrócona” wersja obu słowników, nosząca tytuł: Słownik Bartłomieja z Bydgoszczy: Wersja polsko-łacińska (dalej: Słownik BB). Różnorodne słownictwo Bartłomieja pochodzi z licznych, zarówno rękopiśmiennych (często niedochowanych dziś) źródeł, jak i renesansowych druków (Kędelska, 1997; Słownik BB, cz. 1, ss. 23-35). Znajduje to odbicie w liczbie wyrazów polskich stanowiących w obecnej edycji hasła. W częściach I-VI występuje ponad 10600 wyrazów polskich ${ }^{1}$. Bartłomiej

${ }^{1}$ Warto podkreślić, że według obliczeń Lucyny A. Jankowiak tylko w częściach I-IV Słownika BB znajdują się 244 hasła pochodzące z drugiej wersji słownika (1544), których nie notuje SP XVIw., a także pojawia się 288 nowych znaczeń dla wyrazów zamieszczonych w SP XVIw. (Jankowiak, 2010, ss. 35-41).

This is an Open Access article distributed under the terms of the Creative Commons Attribution 3.0 PL License (creativecommons.org/licenses/by/3.0/pl/), which permits redistribution, commercial and non-commercial, provided that the article is properly cited. (c) The Author(s) 2021.

Publisher: Institute of Slavic Studies, Polish Academy of Sciences

[Wydawca: Instytut Slawistyki Polskiej Akademii Nauk] 
uchodzi dziś za najwybitniejszego leksykografa polskiego pierwszej połowy XVI w. (Wydra \& Rzepka, 2004, ss. 209, 439)².

Artykuł nawiązuje do najstarszej - jak można sądzić - zachowanej w języku polskim terminologii gramatycznej, występującej w łacińsko-polskich rękopisach Bartłomieja. Celem artykułu jest głównie przedstawienie i w niewielkim stopniu analiza formalna słownictwa polskiego, związanego z łacińską kategorią NOMEN. Wybór nomen podyktowany był przez samego słownikarza, który spośród 8 łacińskich części mowy swój wykład rozpoczął od nomen. Za podstawę a nalizy przyjmuję Słownik BB, przy czym dla porównania przytaczam dwa inne źródła, które podejmują zagadnienia gramatyki opisowej (o czym niżej). W toku rozważań spróbuję poruszyć kwestię stosunku polszczyzny do terminów łacińskich i wzajemnych relacji obu języków. Pozostałe części mowy zostaną omówione w osobnych artykułach. Zacznę od krótkiego opisu źródeł.

Manuskrypt z 1532 r. wydał pod koniec XIX w. Bolesław Erzepki. Słownik z 1544 r., który odkryła Irena Kwilecka (Kwilecka, 1972b, 1979, ss. 35-36; Kwilecka \& Popowska-Taborska, 1977, ss. 48-66; Słownik BB, cz. 1, ss. 21-23), jest drugą - znacznie bogatszą pod względem leksykalnym - wersją rękopisu z 1532 r. Są to glosy marginesowe i międzywierszowe zamieszczone w łacińskim inkunabule znanego humanisty Jana Reuchlina z 1488 r. (tym samym, który był wzorcem dla słownika Bartłomieja z 1532 r.). Do właściwych słowników Bartłomiej dołączył jeszcze po kilka kart w układzie rzeczowym, czyli nomenklatory. W leksykonie z 1544 r. znajdują się m.in. terminy specjalne, w tym gramatyczne. „O uświadamianiu odrębności terminologii gramatycznej wobec innych działów leksyki świadczy sporządzony przez Bartłomieja z Bydgoszczy nomenklator De terminis in grammatica..." (Decyk-Zięba, 2020, s. 63).

Supremacja łaciny w średniowieczu i odrodzeniu w dydaktyce szkolnej oraz uniwersyteckiej sprawiała, że ciągle wzrastał popyt na podręczniki do nauki języka łacińskiego. Niektóre z nich zawierały fragmenty tłumaczone na język polski jako

${ }^{2}$ Na temat rękopiśmiennych słowników Bartłomieja, samego autora i jego twórczości zob. Wstęp oraz notę Od autorek do I części Słownika BB (Słownik BB, ss. 7-53), gdzie znajduje się ważniejsza literatura przedmiotu. Zob. też Bibliografię do obecnej edycji, dołączoną wraz z uzupełnieniami do każdej publikowanej części.

${ }^{3}$ Por. Erzepki, 1900; zob. Bibliografię do Słownika BB sv. Erzepki B. Na temat rękopisu z 1532 r. powstało wiele opracowań (m.in. Kwilecka, 1972a, 1979; Kwilecka \& Popowska-Taborska, 1977, ss. 26-47; zob. też Słownik BB, cz. 1, ss. 16-21, 37-46). 
język pomocniczy. Tak np. w gramatyce łacińskiej z 1518 r., opracowanej przez Polaka - Stanisława Zaborowskiego pt. Grammatices rudimenta seu octo partium orationis examen - przytoczone formy czasownika zaopatrzone są w przekład polski, np. voco - zowię, invoco - wzywam (Cytowska, 1968, s.29).

W 1532 r., wychodzi w oficynie M. Szarffenberga podręcznik do nauki języka łacińskiego opracowany przez Jana Hontera pt. Io. Honter Coronensis de grammatica libri duo... ${ }^{4}$. Jest to drugie wydanie gramatyki Hontera, w której znajdują się tłumaczenia fragmentów na język polski pióra Franciszka Mymera. W przedmowie do drugiego wydania gramatyki Hontera Mymer pisze, że gramatykę tę (chodzi o pierwsze niezachowane wydanie) wykładał w Akademii i że cieszyła się ona dużą popularnością. Teraz zatem wydaje ją po raz drugi, wprowadzając uzupełnienia w postaci tłumaczeń trudniejszych wyrażeń i powiększenia liczby przykładów. Jego przekład sprowadza się jednak do tłumaczenia pojedynczych słów, stanowiących przykłady. Tak np. przy analizie słowotwórczej łacińskich deminutiwów (w podrozdziale: De formatione diminutivorum) czytamy: pisciculus - rybka, avicula - ptaszek, pectusculum sierduszko itd. (Cytowska, 1968, s. 49).

Tego typu książeczki z pierwszej połowy XVI w. (z polskimi przykładami) bądź to zaginęły, bądź nie zawierają łacińskiej terminologii gramatycznej w tłumaczeniu polskim.

Władysław Nehring wymienia gramatykę Donata z międzywierszowym przekładem polskim z 1583 r. pt. Aelii Donati Vetustissimi Grammatici Elementa una cum traductione Polonica (Nehring, 1881)5. Cytowane są tam łacińskie terminy gramatyczne, których polskie odpowiedniki, zdaniem Nehringa, zostały przejęte z praktyki szkolnej. Nehring przytacza wiersz F. Mymera, który znajduje się na odwrocie karty tytułowej. Ponieważ Mymer napisał przedmowę (kierowaną do Stanisława Bonera) do drugiej edycji gramatyki Hontera (1532 r.), stąd wniosek Nehringa, że autorem tłumaczenia polskiego był Franciszek Mymer.

Jan Łoś z kolei porównał materiał językowy zawarty w dziele z 1583 r. (dalej: Donat) z polskimi terminami gramatycznymi występującymi w trójjęzycz-

${ }^{4}$ Dziełko jest też dostępne w Dolnośląskiej Bibliotece Cyfrowej. https://dbc.wroc.pl /dlibra/publication/7659/edition/6988

5 Estreicher wymienia Grammatici Elementa (Estreicher, 1897, s. 285). Opis zabytku pochodzi od Nehringa. Książeczka - jak można przypuszczać - nie zachowała się (Cytowska, 1968, ss. 33-34; Koronczewski, 1961, s. 10). 
nym (łacińsko-polsko-niemieckim) podręczniku do nauki łaciny pt. Regulae grammaticales, regimina et constructiones, Kraków 1542 (M. Szarffenberg) (dalej: Reguły). Autor wywnioskował, że Reguły (1542) i gramatyka Donata z 1583 r. to różne wydania tego samego dzieła, które mogło być przekładem Mymera, i które pierwotnie było wydane ok. 1530 r. (Łoś, 1922, s. 109) ${ }^{6}$. Łoś w swej Gramatyce z 1925 r. cytuje ponad 40 terminów gramatycznych z Reguł, nie wspominając już jednak o możliwym udziale Mymera w ich przekładzie na język polski, a co więcej - pisze, że terminologia ta została opracowana przez Andrzeja Glabera z Kobylina (Łoś, 1925, ss. 205-206).

Wypisy i wnioski Nehringa oraz Łosia posłużyły Koronczewskiemu (Koronczewski, 1961, ss. 10-12) ${ }^{7}$ do omówienia jednych z najstarszych zapisów gramatycznych w języku polskim, które pochodziły z zachowanych z opisów książeczek. Koronczewski przychyla się do hipotezy o autorstwie Mymera wydanego ok. $1530 \mathrm{r}$. wspólnego źródła dla Reguł z 1542 r. i Donata z 1583 r. ${ }^{8}$

Zapisane przez Bartłomieja z Bydgoszczy łacińskie terminy gramatyczne $\mathrm{z}$ ich polskimi odpowiednikami zasługują na szczególną uwagę. Po pierwsze dlatego, iż jest to - jak już wspomniano - najstarszy zachowany dotąd w języku polskim zbiór słownictwa z tej dziedziny (Kwilecka, 1972b, ss. 254-256; Kwilecka \& Popowska-Taborska, 1977, ss. 54-56; Łuczak, 1999, ss. 333-336). Po drugie, niektóre z podanych przez Bartłomieja terminów gramatycznych występowały także w Regułach (1542) i u Donata (1583), których słownictwo dzięki wypisom Łosia uwzględnił w swej pracy Koronczewski. Po odkryciu słownika Bartłomieja z 1544 r. (dalej: R) okazało się, że zamieszczona tam łacińska terminologia gramatyczna $\mathrm{z}$ wersją polską odzwierciedla wczesne próby jej powstawania w języku ojczystym.

Pojawiające się w tytule artykułu wyrażenie „w rękopisach” wymaga uściślenia. W pierwszym opracowaniu słownika z 1532 r. (dalej: S) niewiele jest łacińskich terminów gramatycznych zdefiniowanych po polsku, poza tym nie zawsze jest pewność, czy można je za takie uważać. Tak np. łacińska nazwa

${ }^{6}$ Regulae grammaticales z 1542 r. z przekładem polskim (przypisywanym Andrzejowi Glaberowi z Kobylina (Estreicher, 1899, 329)) również - jak uznali badacze - zaginęły (Cytowska, 1968, ss. 33-34; Koronczewski, 1961, s. 10; Skubalanka, 1959, s. 20).

7 Parę lat później Bogusława Żabska zarzuciła Koronczewskiemu, że nie zaznaczył w swej książce, iż za autora Reguł uchodził w językoznawstwie Andrzej Glaber z Kobylina (Żabska, 1965, s. 259).

8 O Mymerze jako autorze takiego opracowania piszą Ogrodziński i Rospond (Ogrodziński, 1946, s. 46; Rospond, 1948, ss. 95-96), opierając się na wnioskach Nehringa i Łosia. 
figura to - kształt, wyobrażenie ${ }^{9}$ (S), czyli dosłowne tłumaczenie łacińskiego wyrazu. Jednak ten sam przykład pojawia się jako accidens verbi na wyklejce przedniej oprawy druku Wokabularza Reuchlina, gdzie występują terminy gramatyczne (o czym niżej).

Dopiero w R, a więc dwanaście lat po napisaniu S, dochodzi nowy dział, obejmujący ok. 300 wyrazów polskich, które wchodzą w skład odpowiedników dla podstawowych pojęć łacińskich z zakresu gramatyki (Kwilecka \& Popowska-Taborska, 1977, ss. 54-56). Słownictwo gramatyczne Bartłomiej zapisywał przeważnie wielokrotnie:

1) gromadził je na dwóch kartach (w nomenklatorach) Wokabularza Reuchlina, tj. na wyklejce przedniej oprawy druku (RN wykl. przednia) i na jego karcie tytułowej (RN k.tyt.);

2) notował je także wewnątrz inkunabułu pod odpowiednimi literami alfabetu.

Towarzyszące niekiedy tym terminom dopiski, np. vide Donatum lub vide Donatum Polonicum, informują, że Bartłomiej korzystał m.in. z popularnej gramatyki Aeliusa Donata. Źródłem była zapewne jej przeróbka bądź inne podręczniki do nauki języka łacińskiego, „które utrzymywały tradycyjny tytuł Donatus, co stało się właściwie synonimem gramatyki elementarnej" (Cytowska, 1968, s. 13). Leksykograf korzystał również z takich źródeł, jak słownik Reuchlina, Kalepina czy słowniczki Mymera i Murmeliusza (Mu28, 1528/1997) ${ }^{10}$.

Cała prawie wyklejka przednia i karta tytułowa druku Reuchlina zostały zapisane hasłami z zakresu gramatyki. Obliczyłam, że te dwie karty zawierają ponad 100 łacińskich terminów gramatycznych, które mają polskie odpowiedniki, ale nie uwzględniłam ilustrujących je przykładów (typu ... ut magistri mistrzowie). Na wyklejce przedniej, w lewej kolumnie pod napisem Indeclinabilia sunt podał słownikarz 19 lacińskich nazw urzędników lub osób pełniących nadworne funkcje, z których 13 ma objaśnienia polskie

9 Wyrazy polskie podaję w transkrypcji. W cytowanych tu przykładach kolejność słów jest przeważnie inna niż w Słowniku BB. Tutaj punktem wyjścia jest hasło łacińskie, następnie zaś odpowiednik polski (tak samo zresztą jak w oryginałach). W wersji „odwróconej” Słownika $\mathrm{BB}$, czyli polsko-łacińskiej, po polskim wyrazie hasłowym następują cytaty ilustrujące użycie danego leksemu polskiego. Podkreśleniem wyróżniam odpowiedniki polskie ze Słownika BB.

10 Dictionarius Ioannis Murmellii variarum rerum ... cum Germanica atque Polonica interpretatione ... (1528/1997). 
typu $a b$ accidentibus ... co pisze stare dzieje; ab epistolis ... kanclerz itp. Zbiór ten stanowi właściwie wyjątek, bowiem egzemplifikacja terminów gramatycznych występujących u Bartłomieja jest ograniczona, co utrudnia zadanie przy próbie określenia schematu gramatyki, którą posłużył się słownikarz ${ }^{11}$. W prawej kolumnie pod tytułem De terminis in grammatica Bartłomiej przedstawił 8 części mowy. Nazwy te częściowo powtórzył na karcie tytułowej (zniszczonej i trudno czytelnej), a częściowo uzupełnił wprowadzając nowe hasła.

Poniżej przytaczam terminologię gramatyczną na podstawie Słownika BB, starając się - na tyle, na ile jest to możliwe - zachować schemat podany przez słownikarza na wyklejce przedniej i karcie tytułowej druku Reuchlina z $1544 \mathrm{r}^{12}$, uzupełniając go nazwami pochodzącymi z różnych miejsc z S i R ${ }^{13}$. Po omówieniu łacińsko-polskiej terminologii gramatycznej Bartłomieja z Bydgoszczy podaję ekwiwalenty polskie z Reguł (Koronczewski, 1961, ss. 10-11; Łoś, 1925, ss. 205-206) i z gramatyki Donata (1583) (Koronczewski, 1961, s. 11; Nehring, 1881, s. 468; $)^{14}$. Niezwykle pomocnym dla badań nad leksyką z zakresu gramatyki jest projekt utworzenia Słownika historycznego terminów gramatycznych, który w 2023 r. zostanie sfinalizowany. Już teraz można korzystać z materiału zarejestrowanego w SHGT (Decyk-Zięba, 2020, s. 60). Na karcie tytułowej Bartłomiej zapisał:

1. Partes oracionis części mowy, działy, rozdziały $\mathrm{RN}$ (k.tyt); pars oracionis część mowy $\mathrm{R} \mathrm{y}_{5} \mathrm{v}$ (md) (f=2).

Na wyklejce przedniej z kolei słownikarz wymienił części mowy w takim oto porządku: verbum, adverbium, participium, nomen, pronomen, coniunctio,

11 M. Cytowska (Cytowska, 1968, ss. 85-101) podaje tablice z układem najczęściej spotykanych podręczników gramatyki łacińskiej.

${ }^{12}$ Reprodukcje obu kart zob. Kwilecka \& Popowska-Taborska, 1977 (rep. 10 i 11); zob. też słownik Bartłomieja z 1544 r. dostępny w wersji internetowej pt. Vocabularius breviloquus https://www.wbc.poznan.pl/publication/11238

13 Przytaczam także dokładne lokalizacje wyrazów (za Słownikiem BB), np. S 58v = Słownik z 1532 r., karta 58 verso; $\mathrm{R} \mathrm{y}_{4} \mathrm{~V}$ = hasło łac. z druku Reuchlina i dopisek polski z 1544 r., karta $\mathrm{y}_{4}$ verso; $\mathrm{ml}, \mathrm{mp}$, md, $\mathrm{mg}=$ margines lewy, prawy, dolny, górny, które oznaczają, że całe hasło łac.-pol. jest zapisane na marginesie; av. = ad vocem, sv. = sub voce. Podanie lokalizacji $\mathrm{w}$ artykule uznałam za słuszne, ponieważ informują one o skojarzeniach wyrazowych autora, a także pomagają szybko ustalić frekwencję haseł łacińskich z polskimi odpowiednikami (f). Zmieniam tylko wielkość liter.

14 W opracowaniu Łosia i Koronczewskiego łacina podana jest w wersji klasycznej. 
preposicio, interiectio ${ }^{15}$. Objaśnienia związane z terminem nomen przedstawiają się następująco:

2. Nomen imię każdej rzeczy RN (wykl. przednia) ( $\mathrm{f}=1)$.

3. Nomen appellativum pospolite (Nom. sing. n.) RN (k.tyt.); a. n. in grammatica pospolite (Nom. sing. $\mathrm{n}$.) $\mathrm{R} \mathrm{c}_{5}$ (ml; appellatio); a. n. est illud, quod naturaliter commune est multorum imię każdej rzeczy (sv. nomen) $\mathrm{R}_{1} \mathrm{v}(\mathrm{f}=3)$.

4. Accidens 'kategoria, właściwość, wyróżnik' przypadność, przypadek, przygoda RN (k.tyt.); a. przygodność, res, que accidit, adest subiecto, ut albedo, nigredo, rotunditas, longitudo etc., przydcza, przygoda, przypadek $\mathrm{S} 3 \mathrm{v} ;$ a. przygodność, przypadek, przydcza, przygoda $\mathrm{R} \mathrm{a}_{3}(\mathrm{md}) ; a$. przypadek $\mathrm{R} \mathrm{M}_{2} \mathrm{~V}$ (mh; av. accido, -ere); accidencia przygodności, przypadłości $\mathrm{R} \mathrm{a}_{3}(\mathrm{md})(\mathrm{f}=5)$.

15 U Donata podstawowy kanon zawierający omówienie 8 części mowy miał następujący schemat: nomen, pronomen, verbum, adverbium, participium, coniunctio, praepositio, interiectio (CGL). Jak informuje Cytowska, były też książeczki rozpoczynające interpretację części mowy od verbum (Cytowska, 1968, s. 12, przyp. 5). Oto wykład 8 części mowy podany przez Bartłomieja: 1. Verbum 'czasownik' sprawowanie, słowo RN (wykl. przednia); $v$ słowo, agere sprawiać, pati cirpieć aut neutrum żadne z tych significans znamionując $\mathrm{RN}$ (k.tyt.); <verbum $\rangle$, agere aliquid sprawiać nieco aut pati abo cirpieć aut neutrum abo żadne z tych significans znamionujac, vide Donatum Polonicum $\mathrm{R} \mathrm{M}_{2} \mathrm{v}$ (md; av. ago,-ere) $(\mathrm{f}=3)$. W ostatnim przykładzie brak hasła verbum, ale nie ma wątpliwości, że o nie właśnie chodzi. Por. CGL, Donati ars minor: de verbo, 591: uerbum quid est? pars orationis cum tempore et persona sine casu aut agere aliquid |aut pati aut neutrum significans. Gramatyka Donata składała się z dwóch części: Ars minor i Ars maior. Ars minor była od IV do XVIII w. podstawowym podręcznikiem do nauki języka łacińskiego. Ułożona $\mathrm{w}$ formie pytań i odpowiedzi ułatwiała zapamiętanie przekazywanych reguł (Curtius, 1997, s. 49). 2. Adverbium 'przysłówek' przysłowie, ktore kładziemy wedle verbum ku wyjaśnieniu RN (wykl. przednia); a. i. allocutio przysłowie, ktore kładziemy wedle verbum ku wyjaśnieniu, co ku słowu przykładamy $\mathrm{R} \mathrm{b}_{1} \mathrm{v}(\mathrm{f}=2)$. 3. Participum 'imiesłów' ktore część bierze od nomen i część od verbum RN (wykl. przednia); p. uczęśnik RN (k.tyt.); p. części branie R y ; uczęśnik, ktore część bierze od nomen i część od verbum (sv. participium) R y y $_{6}$ (m); duo participia dwa uczęśnicy R y ${ }_{6}(\mathrm{mh}$; av. participium) (f=5). 4. Nomen imię każdej rzeczy RN (wykl. przednia) $(\mathrm{f}=1)$. 5. Pronomen 'zaimek' ktore kładziemy na ono miesce, gdzie miało być nomen, namiastek, zamiona RN (wykl. przednia); $p$. zamiona, namiastek in grammatica, ktore kładziemy na ono miesce, gdzie miało być nomen $\mathrm{R} \mathrm{B}_{5} \mathrm{v}(\mathrm{md})(\mathrm{f}=2)$. 6. Coniunctio 'spójnik' spojenie, złączenie $\mathrm{RN}$ (wykl. przednia); c. est quedam pars orationis indec $<$ linabilis $>$ spojenie, złączenie $\mathrm{R}_{3} \mathrm{v}(\mathrm{f}=2)$. 7. Preposicio 'przyimek' na przodku chodzace, przełożenie RN (wykl. przednia); prepositio $\left\{\right.$ in grammatica\} przełożenie, przepołożenie, przekładanie, na przodku chodzace $\mathrm{R}_{2} \mathrm{v}(\mathrm{f}=2)$. 8. Interiectio 'wykrzyknik' podrzucenie, wdanie RN (wykl. przednia); interiectio, quedam pars orationis indeclinabilis apud Latinos wdanie, podrzucenie, przerzuce $<$ nie $>$, wrzucenie $\mathrm{R}_{2}(\mathrm{f}=2)$. 
5. Accidunt nomini przypadaja $\mathrm{RN}$ (wykl. przednia); ts. RN (k.tyt.); $\mathrm{R} \mathrm{a}_{3}$ (md) $(\mathrm{f}=3)$.

$\mathrm{Na} 5$ łac.-pol. haseł z łączną frekwencją $14 \mathrm{w}$ Regułach występuje tylko termin: pospolite (appellativum), ale w opozycji do wyrażenia: imię własne (nomen proprium), którego Bartłomiej nie notuje.

Jako accidens nomnis leksykograf wymienia łac. podkategorię figura $\mathrm{z}$ łączną frekwencją = 9:

6. Figura kształt, wyobrażenie $\mathrm{S} 58 \mathrm{v}$ i $\mathrm{R}_{7}(\mathrm{f}=2)$.

7. Figura simplex prosty kształt, ut doctus 'uczony' RN (wykl. przednia) i R $\mathrm{m}_{7} ; f$. kształt simplex prosty, ut doctus $\mathrm{RN}$ (wykl. przednia) ( $\left.\mathrm{f}=3\right)$.

8. Figura composita składany kształt, złożony RN (wykl. przednia); composita składany RN (wykl. przednia); f.c. składany $\mathrm{R}_{7}$ (md; av. figura simplex); figura composita in grammatica nominum złożone wyobrażenie jimion, ut indecens niesłuszny, impotens niemocny $\mathrm{R}_{2}$ (mp; av. compono,-ere) $(\mathrm{f}=4)$.

Tuż po objaśnieniu „figury” pojawiają się nazwy związane z przypadkiem:

9. Casus 'przypadek' spadek accidens nominis RN (wykl. przednia); casus ... tertio est accidens nominis spadek $\mathrm{R}_{4} \mathrm{v}(\mathrm{f}=2)$.

10. Declinacio skłanianie, wstaczanie RN (wykl. przednia); declinacio casuum, inflexio skłanianie, inclinacio RN (wykl.przednia); declinatio i. inclinatio, inflexio wstaczanie, skłanianie $\mathrm{R}_{5} \mathrm{v}(\mathrm{f}=3)$.

W formie czasownikowej:

11. Declinare in grammatica postąpić, skłaniać się, staczać się, ułożyć, ustanowić, vide Calepi $\mathrm{R} \mathrm{N}_{5} \mathrm{v}$ (md) ( $\left.\mathrm{f}=1\right)$.

Na osobne wyszczególnienie zasługują zapisane przez Bartłomieja polskie nazwy przypadków. Warto podkreślić, że oprócz form imiesłowowych występują formy rzeczownikowe „utworzone od imiesłowu za pomocą formantu -ek, spełniającego funkcję strukturalną, substantywizującą" (Kwilecka, 1972, s. 256). Oto przykłady:

12. Nominativus casus mienionek, mieniący, mianujacy spadek, imieniak RN (wykl. przednia); c.n. mieniący, mianujacy spadek, mien $<i>$ onek, imieniak $\mathrm{R} \mathrm{x}_{1} \mathrm{v}$ (md; av. nomen) ( $\left.\mathrm{f}=2\right)$. 
13. Casus genitivus rodzacy, przez ktorego pytamy, czyja jest rzecz RN (wykl. przednia); genitivus ... pro quodam casu rodzacy $\mathrm{R} \mathrm{n}_{6} \mathrm{v} ; c . g$. przez ktorego pytamy, czyja jest rzecz $\mathrm{R} \mathrm{n}_{6} \mathrm{v}$ (md; av. genitivus) ( $\mathrm{f}=3$ ).

14. Dativus dajacy, dawanek ( $\mathrm{RN}$ wykl. przednia); dativus, pro tertio casu dawajacy $\mathrm{R}_{4} \mathrm{v}$; dativus in gramatica dawanek $\mathrm{R}_{4} \mathrm{v}(\mathrm{md})(\mathrm{f}=3)$.

15. Accusativus oskarżajacy, skarżanek $\mathrm{RN}$ (wykl. przednia); a. casus skarżanek $\mathrm{R} \mathrm{a}_{3}(\mathrm{mg}) ;$ a. casus oskarżający $\mathrm{R}_{2}(\mathrm{md})(\mathrm{f}=3)$.

16. Vocativus wzywajacy, wołanek, zowanek $\mathrm{RN}$ (wykl. przednia) $(\mathrm{f}=1)$.

17. Ablativus precz bierzacy, oddalonek, ut doctior illa, doctior illis ..., odbierajacy RN (wykl. przednia); ablativus ... ponitur pro casu \{ut doctior illa, doctior illis\} precz bierzacy, odbierajacy $\mathrm{R}_{2} ;$ a. casus in grammatica odbierajacy, precz bierzaç vel $i$. oddalonek $\mathrm{R}_{2}$ (md) ( $\mathrm{f}=3$ ).

Bartłomiej wylicza 6 przypadków, które pochodzą tylko z drugiej wersji słownika, czyli z R, z frekwencją $=15$. W sumie występuje tu 9 (razem z casus, declinacio i declinare) łac. haseł tłumaczonych na język polski, z łączną liczbą użyć 21. W Regułach i w gramatyce Donata (1583) pojawiają się następujące określenia w formie przydawki imiesłowowej, które poświadczone są również przez Bartłomieja: spadek mieniący, mianujący, rodzący, dawający, oskarżający, wzywający (czyli 6 odpowiedników) oraz takie nazwy, jak declinatio skłonienie, staczanie (Bartłomiej - skłanianie, wstaczanie), declinare staczać, skłaniać (Bartłomiej + się).

Zgodnie z przepisami gramatyki Donata również stopniowanie jest właściwością nomen. Bartłomiej wyróżnia trzy stopnie przymiotników i wprowadza za Donatem i drukiem Reuchlina następujące sformułowania:

18. Comparacio przyrownanie RN (wykl. przednia); c. przyrowność, $<$ przyrow $>$ nanie, przyrownanie $\mathrm{R} \mathrm{h}_{1} \mathrm{v}$ (md) (f=2).

19. Hic comparativus et hoc comparativum przyrownanie (sv. comparativus, $-a,-u m) \mathrm{R}_{1} \mathrm{v}(\mathrm{f}=1)$.

20. Que nomina comparantur $<$ ? >, i. Donatus mnożą sie, przyrownają się RN (k.tyt.); Donatus: Que nomina comparantur <? > mnożą się i przyrownają $\mathrm{R}_{1} \mathrm{v}$ (md; av. comparacio) ( $\left.\mathrm{f}=2\right)$.

21. Positivus gradus przedni, ut doctus, położony wstopień RN (k.tyt.); positivus gradus $d r$ eo, quod ponatur primus in comparationis gradibus, quasi fundamentum graduum pirwsze położone słowo, przedni stopień położony $\mathrm{R} \mathrm{A}_{6} \mathrm{v}$; positivus - przedni, ut doctus, doctior comparativus $\mathrm{R}_{1} \mathrm{v}(\mathrm{md})(\mathrm{f}=3)$. 
22. Comparativus gradus in grammatica przyrownajacy stopień $\mathrm{R} \mathrm{h}_{1} \mathrm{v}(\mathrm{md})$; comparativus gradus stopień przyrownajacy RN (wykl. przednia), comparativus pirwsze gradus, ut doctior przyrownajacy $\mathrm{RN}$ (k.tyt.) (f=3).

23. Superlativus $<$ gradus $>$ nadwyszszy stopień, przewyszszajacy, ut doctissimus nauczeńszy RN (wykl. przednia); $s .<g$.> przewyszszający, nadwyszszy, ut doctissimus $\mathrm{RN}$ (k.tyt.); superlativus przewyszszający $\mathrm{R} \mathrm{h}_{1} \mathrm{v}(\mathrm{md})(\mathrm{f}=3)$.

Na 6 nazw łacińskich frekwencja haseł łac.-pol. wynosi tutaj 14. W Regułach i u Donata (1583) występują takie odpowiedniki, jak: positivus gradus przedni, położony, gradus comparativus stępień (Bartłomiej - stopień) przyrownający, gradus superlativus stępień (Bartłomiej - stopień) przewyższający, przewyszszający (4 ekwiwalenty).

Po wymienieniu stopni przymiotników Bartłomiej przechodzi do genus, następnej kategorii nomen, i wyróżnia 7 rodzajów:

24. Genus rodzaj RN (wykl. przednia); genus plura signat ... item capitur pro accidente partium orationis rodzaj $\mathrm{R}_{7}(\mathrm{f}=2)$.

25. Masculinum genus męski rodzaj $\mathrm{R}_{1}$ (mp; av. masculinus) $(\mathrm{f}=1)$.

26. Genus neutrum oddzielne, ut hoc scamnum 'lawka' ani męskie, ani niewieście $\mathrm{R}_{6} \mathrm{~V}$ (md); neuter żaden $\mathrm{z}$ tych $\mathrm{RN}$ (wykl. przednia); neutri generis, lignum oddzielnej lidżby $\mathrm{R}_{6} \mathrm{v}(\mathrm{md})(\mathrm{f}=3)$.

27. Epicenum genus zamieszany rodzaj, gdzie nie możemy rozeznać, jestli ta abo ona rzecz jest, ut sunt passer 'wróbel' aquila 'orzeł', milvus 'jastrząb' (RN wykl. przednia); epicenum i. promiscuum genus pospolity, zamieszany rodzaj, gdzie nie możemy rozeznać, jestli ta abo ona rzecz jest, $u t$ hic passer, mustela 'łasica', milvus $\mathrm{R}_{1} \mathrm{v}(\mathrm{md})(\mathrm{f}=2)$.

28. Promiscuum ..., item promiscuum genus in nomine quod Grece epicenum, $i$. supra commune dr, est quod sub una voce et uno articulo comprehendit animalia utriusque sexus \{zamieszany rodzaj, vide supra epicenum\} $\mathrm{R} \mathrm{B}_{5} \mathrm{v}^{16}(\mathrm{f}=1)$.

29. Dubium genus watpliwy rodzaj, ut hic aut hec dies 'dzień' RN (wykl. przednia); d. g. watpliwy rodzaj, ut hic aut hec dies $\mathrm{R}_{7}$ (md; av. genus) ${ }^{17}(\mathrm{f}=2)$.

16 Epicenum = promiscuum genus jest to mieszany rodzaj rzeczowników (głównie nazw zwierząt), które nie rozróżniają rodzaju naturalnego i określają zarówno samca, jak i samicę.

17 Dubium genus dotyczy rzeczowników, które mogą mieć rodzaj gramatyczny żeński lub męski. 
30. Omne genus ktory wszytko troje ma w sobie, ut hic et hec et hoc felix 'szczęśliwy' RN (wykl. przednia); omne genus in grammatica ktory wszytko troje ma w sobie, $\mathrm{i}$ ten, $\mathrm{i}$ ta, $\mathrm{i}$ to szczesne $i$. hic et hec et hoc felix $\mathrm{R}_{7}$ (md; av. genus $^{18}(\mathrm{f}=2)$.

31. Commune genus pospolity rodzaj, i męski i niewieści, ut hic et hec homo 'człowiek' aut virgo 'dziewica, dziwczyna; młodzieniec' aut sacerdos 'kapłan; kapłanka' jako ten i ta kapłan R (wykl. przednia); c.g. pospolity, i męski, i niewieści, ut hic aut hec homo, virgo, latro 'rozbójnik, łotr' panna, panicz $\mathrm{R}_{7}$ (md; av. genus); <genera > communia pospolite (Nom. plur. n.) RN (k.tyt.) $(\mathrm{f}=3)^{19}$.

Na 8 haseł łacińskich frekwencja nazw z odpowiednikami polskimi wynosi 16 , w tym niepowtarzających się cytatów pol. jest 14 . W Regułach i u Donata odnajdujemy, podobnie jak u Bartłomieja, hasła: genus masculinum rodzaj męski, genus neutrum oddzielny.

Następnym hasłem jest numerus, czyli liczba. Sądząc po przykładach i ich lokalizacji niewątpliwie chodzi tu o kategorię nomen.

32. Numerus liczba RN (wykl. przednia) ${ }^{20}(\mathrm{f}=1)$.

33. Numerus singularis co jednego znamionuje, ut magister 'nauczyciel', jedna liczba RN - (wykl. przednia); $n$. s. jedna lidżba, $u t m<$ agiste $>r$ RN (k.tyt.); n. s. co jednego znamionuje, ut magister, jedna lidżba $\mathrm{R}_{3}$ (mp; av. numerus); singulares (!) jednej lidżby $\mathrm{R}_{8}(\mathrm{mp}$; av. singulus) $(\mathrm{f}=4)$;

34. Numerus pluralis co wiele znamionuje, ut magistri mistrzowie RN (wykl. przednia); $n$. p. wielga liczba, ut magistri RN (k.tyt.) ( $\mathrm{f}=2)$.

35. Numerale nomen aut verbum słowo, co znam<io>nuje liczbę RN (k.tyt.); $n$. $n$. słowo, co liczbe znamionuje $S 98 \mathrm{v}$; numerale nomen i. verbum słowo, co znamionuje lidżbę $\mathrm{R}_{3}(\mathrm{mp})(\mathrm{f}=3)$.

Mamy tu łącznie 4 hasła łac.-pol. z frekwencją równą 10. Objaśnień polskich jest 9. Przy czym termin numerale nomen należy rozumieć jako osobną

18 Omne genus oznacza, że przymiotniki mają te same końcówki deklinacyjne dla wszystkich trzech rodzajów.

${ }^{19}$ Commune genus wskazuje, że rzeczowniki (zwłaszcza osobowe) nie rozróżniają rodzaju naturalnego i mogą oznaczać kobietę, jak i mężczyznę.

20 Przykład ten występuje też w słowniczku Murmeliusza: Numerus ... Lyczba (Mu28, 1528/1997, s. 197). 
kategorię gramatyczną, czyli - liczebnik. W Regułach i u Donata mamy jeden polski odpowiednik porównywalny do wyrażenia występującego u Bartłomieja: numerus pluralis liczba wielka (Bartłomiej - wielga liczba).

Po objaśnieniu terminu numerus Bartłomiej podaje nazwy qualitas i quantitas:

36. Qualitas jakość, ut bonus 'dobry', malus 'zły', albedo 'biel', nigredo 'czern', paternitas 'ojcostwo', filiacio 'synostwo' RN (wykl. przednia); qualitas i. secundum quam dicunt quales, ut albedo, nigredo jakość ( $2 \mathrm{x})$, obyczajność S 128; qualitas jakość $\mathrm{R}_{2}(\mathrm{mp})$; qualitas in grammatica jakość, ut bonus, malus, albedo, nigredo, paternitas, filiacio takość $\mathrm{R} \mathrm{C}_{2}(\mathrm{md}) ;(\mathrm{f}=4)$.

Quantitas - nazwa wymieniona na wyklejce przedniej oprawy druku R pod nomen pozostaje bez odpowiednika polskiego. Autor zapisał ją natomiast w S i przy haśle w druku R, gdzie quantitas przedostał się za Ars minor Donata:

37. Quantitas ilość, wielko, mało S 128; quantitas wielkość, ut magnus 'wielki', parvus 'mały' $\mathrm{R}_{2} \mathrm{v}(\mathrm{f}=2)$.

Występują tutaj 2 terminy łacińskie objaśnione po polsku w $\mathrm{R}$ i w S z frekwencją $=6$. Dają one 5 różnych odpowiedników polskich.

W związku z kategorią nomen większość wymienionych przez Bartłomieja odpowiedników polskich to istniejące już w polszczyźnie wyrazy, którym słownikarz nadał nowe, bardziej precyzyjne znaczenia (z wyjątkiem Reguł z 1542 r. i Donata z 1583 r.). Są one dosłownym tłumaczeniem terminów łacińskich i niewiele by nam mówiły, gdyby nie podstawa łacińska. Występujące w S pięć przykładów użyć nazw łacińskich związanych z kategorią nomen to: accidens - przygodność, przydcza, przygoda, przypadek (przykł. 4); figura kształt, wyobrażenie (przykł. 6); numarale nomen - słowo, co liczbe znamionuje (Mu28, 1528/1997, s. 199) (przykl. 35); qualitas - jakość, obyczajność (przykł. 36); quantitas - ilość, wielko, mało (przykł. 37). O ile dwa pierwsze przykłady można uznać za ogólne, słownikowe tłumaczenie wyrazów łacińskich, o tyle trzy kolejne przykłady należą do terminologii gramatycznej, o czym świadczą źródła. Różnica między słownikami z 1532 r. i 1544 r. polega na tym, że nazwy (gramatyczne) z pierwszej wersji leksykonu muszą być poświadczone przez źródło, którym posłużył się Bartłomiej, zaś nazwy z drugiej wersji to nomenklatory z hasłami z zakresu gramatyki (RN wykl. przednia oraz NR k.tyt.) i liczne powtórzenia haseł na marginesach Wokabularza Reuchlina. 
Spisane przez słownikarza polskie nazwy przypadków stanowią unikalny zbiór słownictwa, który oprócz form imiesłowowych zawiera także rzeczowniki utworzone od imiesłowu przy pomocy formantu -ek (przykł. 12-17). Od tego schematu strukturalnego odbiega tylko nazwa imieniak dla łac. terminu Nominativus (Kwilecka, 1972b, s. 256). Rzeczownik wołanek (Vocativus), a ściślej czeski odpowiednik volánek występuje w łacińsko-czeskim wierszowanym Wokabularzu Klareta (połowa XIV w.), a także w łacińsko-czeskim słowniku Jana Vodňanskiego z 1511 r. (tzw. Lactifer).

Frekwencja, czyli liczba użyć łacińsko-polskich haseł w S i R odnoszących się do kategorii nomen (rzeczowniki, przymiotniki) świadczy o tym, że Bartłomiej powtarzał hasła w wielu miejscach, w zależności od konkretnej litery alfabetu, hasła bądź skojarzeń wyrazowych autora, a ogólna liczba poświadczeń wskazuje, ile terminów odnotował słownikarz w zakresie omawianej kategorii w ogóle. Warto nadmienić, że większość zapisanych przez Bartłomieja odpowiedników polskich (lub ich synonimów) nie figuruje w monograficznej rozprawie A. Koronczewskiego.

Terminy spisane przez Bartłomieja obejmują także inne pojęcia gramatyczne, odnoszące się do różnych części mowy.

Tutaj ograniczyłam się tylko do nielicznych przykładów, przede wszystkim wymienienia części mowy i skupieniu się na kategorii nomen. Polskie odpowiedniki - jak można było zauważyć - Bartłomiej starał się oddać poprzez wierne tłumaczenie pojęć łacińskich (kalki tłumaczeniowe) lub przez opisy oparte na łacińskich definicjach poszczególnych nazw. Bartłomiej, dobrze zorientowany w ówczesnej literaturze słownikarskiej, znał wcześniejsze leksykony łacińskie, łacińsko-polskie lub wielojęzyczne i niejeden wyraz lub wyrazy z nich przełożył (np. ze słowników Reuchlina, Kalepina); w przypadku źródeł zawierających język polski - po prostu zaczerpnął (np. ze słownika Murmeliusza ) (Kędelska, 1989, ss. 33-37; Mu28, 1528/1997). Do tego dochodzi jeszcze podręcznik - dziś nam bliżej nieznany - gramatyki łacińskiej z przekładem polskim. Tymczasem wynotowałam 37 haseł łac.-pol. związanych $\mathrm{z}$ nomen (pozostało jeszcze do przedstawienia 7 haseł dotyczących tej kategorii) z frekwencją równą 71. Liczne powtórzenia haseł w słownikach Bartłomieja, wynikają z faktu, że słowniki nie były przeznaczone do druku lecz do użytku studium filozoficznego bernardynów z Bydgoszczy, i powstawały etapami ${ }^{21}$. Analiza haseł gramatycznych u Bartłomieja wymaga jednak

${ }^{21}$ Obszernie na ten temat pisze L. A. Jankowiak (Jankowiak, 2020). 
osobnego, poprzedzonego wnikliwymi studiami porównawczymi, opracowania. Pozwoli ono, być może, ustalić źródło łacińsko-polskiej terminologii gramatycznej Bartłomieja z Bydgoszczy. W osobnych artykułach chciałabym omówić pozostałe tłumaczone na język polski terminy gramatyczne i zastanowić się nad polskimi osobliwościami leksykalnymi w zakresie słowotwórstwa i semantyki.

\section{Bibliografia}

Curtius, E. R. (1997). Literatura europejska i łacińskie średniowiecze. Universitas.

Cytowska, M. (1968). Od Aleksadra do Alwara (Gramatyki łacińskie w Polsce w XVI w.). Zakład Narodowy im. Ossolińskich.

Decyk-Zięba, W. (2020). O kształtowaniu się polskiej terminologii gramatycznej. Poradnik Językowy, 2020(5), 60-75. https://doi.org/10.33896/PorJ.2020.5.5

Dictionarius Ioannis Murmellii variarum rerum ... cum Germanica atque Polonica interpretatione... [Mu28]. (1997). W W. Gruszczyński (Oprac.), Dictionarius Ioannis Murmellii variarum rerum ...; [Francisci Mymeri] Dictionarium trium linguarum. Collegium Columbinum. (Oryginalna praca opublikowana 1528).

Erzepki, B. (1900). Słownik łacińsko-polski Bartłomieja z Bydgoszczy podług rękopisu z r. 1532. Wydał dr B. Erzepki.

Estreicher, K. (1897). Bibliografia staropolska (T. 15). Drukarnia Uniwersytetu Jagiellońskiego

Estreicher, K. (1899). Bibliografia staropolska (T. 17). Drukarnia Uniwersytetu Jagiellońskiego

Holtz, L. (Red.). (1981). Corpus Grammaticorum Latinorum [CGL]. https://cgl.hypotheses.org/1005

Jankowiak, L. A. (2010). Słownik Bartłomieja z Bydgoszczy z 1544 roku wobec leksyki XVI wieku: Uwagi po lekturze Słownika polszczyzny XVI wieku. W E. Skorupska-Raczyńska \& J. Rutkowska (Red.), Między dawnymi a nowymi słowy (ss. 33-45). Państwowa Wyższa Szkoła Zawodowa w Gorzowie Wielkopolskim.

Jankowiak, L. A. (2020). Z warsztatu leksykograficznego Bartłomieja z Bydgoszczy: Powtórzenia haseł. Studia z Filologii Polskiej i Słowiańskiej, 55, Article 1994. https://doi.org/10.11649/sfps.1994

Jankowiak, L. A., Kędelska, E., \& Łuczak, A. (Oprac.). (2019). Słownik Bartłomieja z Bydgoszczy: Wersja polsko-łacińska (Cz. 6). Instytut Slawistyki Polskiej Akademii Nauk. https://hdl .handle.net/20.500.12528/1083

Kędelska, E. (1989). Pierwsze drukowane słowniki łacińsko-polskie jako źródła Bartłomieja z Bydgoszczy. Studia z Filologii Polskiej i Słowiańskiej, 25, 31-45.

Kędelska, E. (1997). Przydatność łacińsko-polskich wokabularzy do badań językoznawczych (zalety i ograniczenia). W H. Popowska-Taborska (Red.), Leksyka słowiańska na warsztacie językoznawcy (ss. 117-125). Instytut Slawistyki Polskiej Akademii Nauk. 
Kędelska, E., Kwilecka, I., \& Łuczak, A. (Oprac.). (1999-2012). Słownik Bartłomieja z Bydgoszczy: Wersja polsko-łacińska (Cz. 1-5). Instytut Slawistyki Polskiej Akademii Nauk. https:// hdl.handle.net/20.500.12528/1083

Koronczewski, A. (1961). Polska terminologia gramatyczna. Zakład Narodowy im. Ossolińskich.

Kwilecka, I. (1972a). Słownik Bartłomieja z Bydgoszczy odnaleziony. Język Polski, 52(3), 180-182.

Kwilecka, I. (1972b). Nieznany zbiór słownictwa polskiego pióra Bartłomieja z Bydgoszczy. Język Polski, 52(4), 252-261.

Kwilecka, I., \& Popowska-Taborska, H. (1977). Bartłomiej z Bydgoszczy: Leksykograf polski pierwszej połowy XVI w. Zakład Narodowy im. Ossolińskich.

Kwilecka, I. (1979). Warsztat pisarski Bartłomieja z Bydgoszczy. W H. Popowska-Taborska (Red.), Bartłomiej z Bydgoszczy i jego dzieło (ss. 23-36). Państwowe Wydawnictwo Naukowe.

Łoś, J. (1922). Początki piśmiennictwa polskiego (2. wyd.). Wydawnictwo Zakładu Narodowego im. Ossolińskich.

Łoś, J. (1925). Gramatyka polska: Część II. Słowotwórstwo. Wydawnictwo Zakładu Narodowego im. Ossolińskich.

Łuczak, A. (1999). Jeszcze kilka uwag o Słowniku Bartłomieja z Bydgoszczy z pierwszej połowy XVI w. Eos, 86(2), 325-337.

Nehring, W. (1881). Eine unbekannte Ausgabe des Donatus mit polnischer Übersetzung. W V. Jagić (Red.), Archiv für Slavische Philologie (T. 5; ss. 466-468). Weidmannsche Buchhandlung.

Ogrodziński, W. (1946). Dzieje piśmiennictwa śląskiego (T. 1). Instytut Śląski; Drukarnia Cieszyńska.

Rospond, S. (1948). Zabytki języka polskiego na Śląsku z 23 ilustracjami. Instytut Śląski.

Skubulanka, T. (1959). Stanowisko O. Kopczyńskiego wobec nowotworów językowych. Zeszyty Naukowe Uniwersytetu Mikołaja Kopernika w Toruniu: Nauki Humanistyczno-Społeczne: Filologia Polska, 1(2), 3-50.

Słownik historyczny terminów gramatycznych [SHTG]. (b.d.). https://shtg.uw.edu.pl

Wydra, W., \& Rzepka, W. R. (2004). Chrestomatia staropolska: Teksty do roku 1543. Zakład Narodowy im. Ossolińskich.

Żabska, B. (1965). Z zagadnień polskiej terminologii gramatycznej: Na marginesie książki A. Koronczewskiego. Rozprawy Komisji Językowej Wrocławskiego Towarzystwa Naukowego, 5, 255-261. 


\title{
Attempts to Create Polish Grammatical Terms: The Case of Manuscripts by Bartholomeus de Bydgostia
}

\author{
Summary
}

This article is devoted to presumably the oldest preserved grammatical terminology in the Polish language, which appears in two Latin-Polish manuscripts by Bartholomeus de Bydgostia of 1532 (S) and 1544 (R). The second dictionary (1544) is especially worth considering as it contains much larger lexical material in the field of grammar. The author made terminological notes mainly in special sections devoted to grammatical terms, which contain about 100 Latin entries with Polish renderings. We can also find such notes on the margins of Johann Reuchlin's print (1488). On the basis of the new (PolishLatin) edition of the dictionary by Bartholomeus de Bydgostia (1999-2019), I present the Latin names of eight parts of speech with the Polish explanations (words, phrases, sentences, etc.) and 37 Latin and Polish headwords connected with the Latin category nomen.

\section{Próby tworzenia polskich terminów gramatycznych. Na przykładzie rękopisów Bartłomieja z Bydgoszczy}

\author{
Streszczenie
}

Artykuł nawiązuje do najstarszej - jak można sądzić - zachowanej w języku polskim terminologii gramatycznej, występującej w łacińsko-polskich rękopisach Bartłomieja z Bydgoszczy z lat 1532 (S) i 1544 (R). Zapisy z dziedziny gramatyki Bartłomiej odnotował głównie w nomenklatorach, gdzie występuje ok. 100 terminów łacińskich z polskimi objaśnieniami, a także na marginesach druku J. Reuchlina. Na podstawie obecnej edycji słownika, zawierającej materiał z S i R, pt. Słownik Bartłomieja z Bydgoszczy: Wersja polsko-łacińska (1999-2019) przedstawiłam nazwy polskie dla 8 łacińskich części mowy oraz kategorii 
nomen, w zakresie różnorodnego doboru słownictwa np. figura - prosty kształt, ut doctus; figura composita in grammatica nominum - złożone wyobrażenie jimion, ut indecens niesłuszny, impotens niemocny. Wyekscerpowałam dla tych pojęć 37 terminów łacińskich z polskimi odpowiednikami.

Keywords: Polish grammatical terminology; dictionaries by Bartholomeus de Bydgostia

Słowa kluczowe: polska terminologia gramatyczna; słowniki Bartłomieja z Bydgoszczy

Arleta Łuczak, Institute of Slavic Studies, Polish Academy of Sciences, Warsaw, Poland ORCID: https://orcid.org/0000-0002-3076-7144

Correspondence: arleta.luczak@ispan.waw.pl

The preparation of this article was self-financed by the author.

Competing interests: The author has declared that she has no competing interests.

Publication history: Received: 2019-05-19; Accepted: 2021-10-06; Published: 2021-12-20 